\title{
Ruminal degradability of dry matter, crude protein, and amino acids in soybean meal, canola meal, corn, and wheat dried distillers grains
}

\author{
G. Maxin, ${ }^{1,2}$ D. R. Ouellet, and H. Lapierre \\ Agriculture and Agri-Food Canada, Dairy and Swine Research and Development Centre, Sherbrooke, Quebec, Canada J1M 0C8
}

\begin{abstract}
Different protein sources, such as canola meal (CM) or dried distillers grains (DDG), are currently used in dairy rations to replace soybean meal (SBM). However, little data exists comparing their rumen degradation in a single study. Therefore, the objective of this study was to compare the ruminal degradation of dry matter (DM), crude protein (CP), and AA of SBM, CM, high-protein corn DDG (HPDDG), and wheat DDG plus solubles (WDDGS). In situ studies were conducted with 4 rumen-fistulated lactating Holstein cows fed a diet containing 38\% grass hay and $62 \%$ corn-based concentrate. Each protein source was incubated in the rumen of each cow in nylon bags for $0,2,4,8,16,24$, and $48 \mathrm{~h}$ to determine DM and CP rumen degradation kinetics, whereas additional bags were also incubated for $16 \mathrm{~h}$ to evaluate AA ruminal disappearance. Rumen DM and CP degradability was calculated from rumenundegraded residues corrected or not for small particle loss. Data were fitted to an exponential model to estimate degradation parameters and effective degradability (ED) was calculated with a passage rate of 0.074 $\mathrm{h}^{-1}$. The WDDGS and SBM had higher uncorrected $\mathrm{ED}(\mathrm{DM}=75.0$ and $72.6 \% ; \mathrm{CP}=84.8$ and $66.0 \%$, respectively) than $\mathrm{CM}$ and $\mathrm{HPDDG}(\mathrm{DM}=57.2$ and $55.5 \% ; \mathrm{CP}=59.3$ and $48.2 \%$, respectively), due to higher soluble fraction in WDDGS and a combination of higher potentially degradable fraction and rate of degradation in SBM. Correction for small particle loss from bags, higher for WDDGS than for the other protein sources, decreased estimated ED but did not alter feed ranking. The ruminal disappearance of AA after $16 \mathrm{~h}$ of incubation reflected the overall pattern of $\mathrm{CP}$ degradation between protein supplements, but the ruminal disappearance of individual AA differed between protein supplements. Overall, these results indicate that, in the current study, (1) SBM and WDDGS were
\end{abstract}

Received November 19, 2012

Accepted April 27, 2013.

${ }^{1}$ Corresponding author: gaelle.maxin@clermont.inra.fr

${ }^{2}$ Present address: INRA UMR 1213 Herbivores, Site de Theix, F-63122, Saint-Genès-Champanelle, France. more degradable in the rumen than CM and HPDDG, and (2) that small particle loss correction is relevant but does not alter this ranking.

Key words: rumen degradation, protein, amino acid, protein supplement

\section{INTRODUCTION}

Canola meal (CM) or dried distillers grains (DDG) are currently used in North American cattle diets as economic alternatives to soybean meal (SBM). Canola is a cultivar of rapeseed low in erucic acid and glucosinate (Bell, 1984; Newkirk, 2009). Oil production from canola in western Canada resulted in the production of approximately 3.5 million t of CM in 2011 (Statistic Canada, 2011). With its protein concentration and AA profile, CM is a by-product well suited for dairy nutrition (Newkirk, 2009; Huhtanen et al., 2011). With continued expansion of the ethanol industry in North America, DDG are becoming common feed ingredient in diets for cattle, used to supply protein and energy (Schingoethe et al., 2009; Zhang et al., 2010). In the United States, DDG is derived from corn, whereas, in Western Canada, it is mainly derived from wheat. Changes in the fractionation process to improve the fermentation of corn to ethanol resulted in new products, such as high-protein DDG, which is closer in nutrient composition (higher in CP and lower in fat) to CM and SBM than conventional DDG (Robinson et al., 2008; Schingoethe et al., 2009). Numerous studies compared substitution of SBM by CM, high-protein DDG, or wheat DDG on milk production and composition (e.g., Christen et al., 2010; Oba et al., 2010; Abdelqader and Oba, 2012) and have shown that feeding these protein supplements may be as effective as feeding SBM to lactating dairy cows.

Few studies, however, have compared rumen degradation of CM or DDG with SBM. According to NRC (2001), 48\% CP solvent-extracted SBM would have a greater RUP fraction than CM (42.6 vs. $35.7 \% \mathrm{CP}$ at DMI of $4 \%$ BW with forage at $50 \%$ DMI). Proteins in DDG would be less degradable than SBM (Kleinschmit et al., 2007), but values vary greatly with grain source and ethanol production process (Li et al., 2012) and 
data on the ruminal $\mathrm{CP}$ and AA degradation of highprotein corn DDG or wheat DDG are limited. Furthermore, to our knowledge, no comparison exists of rumen degradation of all these protein sources in a single study. Despite standardization of the in situ method, data could vary greatly between studies, making it difficult to compare the degradation values (Madsen and Hvelplund, 1994). Estimation of rumen disappearance of feed protein and AA is an essential factor for correct assessment of both RDP and RUP fractions from a feed ingredient and, therefore, calculation of metabolizable proteins and AA digestive flows with the current systems used to balance dairy rations (e.g., NRC, 2001; INRA, 2007); particularly as ruminal disappearance of individual AA could differ within feedstuff resulting in differences between original feed AA composition and RUP AA composition (O'Mara et al., 1997; Li et al., 2012). Therefore, the objective of this study was to compare DM, CP, and AA ruminal degradation of SBM, CM, high-protein corn DDG, and wheat DDG plus solubles using the in situ technique in lactating dairy cows.

\section{MATERIALS AND METHODS}

\section{In Situ Procedure}

Four rumen-fistulated Holstein cows were used for the study, with an average BW of $729 \pm 54 \mathrm{~kg}$ and DIM of $266 \pm 17$ at the start of the experiment. Cows were housed in tie-stalls and milked twice daily at $12-\mathrm{h}$ intervals. They were individually fed a controlled amount of a TMR formulated to meet their energy, protein, mineral, and vitamin requirements (NRC, 2001). The TMR consisted of $38 \%$ grass hay and $62 \%$ corn-based concentrate (Table 1) and was offered in 12 equal meals using automatic feeders. During the in situ study, cows consumed on average $23.6 \pm 1.9 \mathrm{~kg}$ of $\mathrm{DM} / \mathrm{d}$ and produced $29.6 \pm 7.4 \mathrm{~kg}$ of milk/d. The experimental protocol was approved by the Institutional Animal Care Committee of the Sherbrooke Dairy and Swine Research and Development Centre and animals were treated according to the Canadian Council on Animal Care guidelines (CCAC, 1993).

Four protein supplements, provided from the same processing batch, were investigated: solvent-extracted SBM (Vita Plus, Lake Mills, WI), solvent-extracted CM (Bunge, Harrowby, MB, Canada), high-protein corn DDG (HPDDG; Poet's, Albert Lea, MN), and wheat DDG plus solubles (WDDGS; Terra Grain Fuel, Belle Plaine, SK, Canada). In situ ruminal incubations started after $10 \mathrm{~d}$ of adaptation to the diet. Samples of each protein supplement were milled through a $2-\mathrm{mm}$ screen as recommended by NRC (2001) for in situ measurement of CP ruminal degradation. Then, subsamples of each protein supplement $(6.5 \mathrm{~g})$ were placed in $\mathrm{N}$-free polyester bags $(10 \times 20 \mathrm{~cm})$ with a pore size of $50 \mu \mathrm{m}$ (R1020, Ankom, Fairport, NY); the ratio of sample size to surface area bag was $15 \mathrm{mg} / \mathrm{cm}^{2}$. For each protein supplement, simultaneously in each cow, bags were incubated, in duplicate, in the rumen for 2, $4,8,16,24$, or $48 \mathrm{~h}$. Four additional bags were placed in the rumen of each cow and removed after a 16-h incubation to determine the AA ruminal disappearance. Bags $(52 / \mathrm{cow})$ were hooked to a stainless steel weight and all inserted in the ventral rumen at $0800 \mathrm{~h}(\mathrm{~d} 1)$. Then, bags were removed on $\mathrm{d} 1$, at 1000, 1200, and $1600 \mathrm{~h}$, on $\mathrm{d} 2$ at 0000 and $0800 \mathrm{~h}$, and on $\mathrm{d} 3$ at 0800 h. Zero-hour bags were not inserted in the rumen $(\mathrm{n}=$ 3 for each protein supplement).

Once bags were removed from the rumen, they were immersed in 20-L buckets containing cold $\left(4^{\circ} \mathrm{C}\right)$ saline for $15 \mathrm{~min}$. All bags (including 0-h bags) were pummelled through a stomacher (Stomacher 400 Lab Blender, Seward Medical, London, UK; model BA 7021) for 7 min at normal speed in cold $0.9 \%$ saline. Then, bags were washed in a washing machine without detergent until clean water was obtained ( 5 cycles consisting of 1 min delicate washing and 2 min of spinning) and ovendried at $55^{\circ} \mathrm{C}$ for $24 \mathrm{~h}$. Dried bags were individually

Table 1. Ingredients and chemical composition of the basal diet fed during in situ experiment

\begin{tabular}{lc}
\hline Item & \% of DM \\
\hline Ingredient $^{1}$ & \\
Grass hay $^{1}$ & 38.0 \\
Soybean meal $^{1}$ & 13.7 \\
Wheat, ground $^{1}$ & 6.4 \\
${\text { Corn, } \text { ground }^{1}}_{\text {Beet pulp }^{1}}$ & 28.7 \\
Soyhulls $^{1}$ & 7.2 \\
Ca soap of FA $^{2}$ & 3.3 \\
Vitamins and minerals $^{3}$ & 0.5 \\
Chemical composition & 2.3 \\
CP & \\
NDF & 17.1 \\
ADF & 32.5 \\
Ether extract & 19.1 \\
NE ${ }^{4}{ }^{4}$ Mcal/kg & 2.2 \\
\hline
\end{tabular}

${ }^{1}$ Grass hay $=13.2 \%$ CP, $55.7 \%$ NDF, 33.2\% ADF, and $2.2 \%$ ether extract; wheat $=20.3 \% \mathrm{CP}, 39.2 \% \mathrm{NDF}, 14.4 \% \mathrm{ADF}$, and $2.9 \%$ ether extract; corn $=8.7 \% \mathrm{CP}, 9.9 \% \mathrm{NDF}, 3.4 \% \mathrm{ADF}$, and $3.1 \%$ ether extract; beet pulp $=9.0 \% \mathrm{CP}, 38.3 \% \mathrm{NDF}, 27.9 \% \mathrm{ADF}$, and $0 \%$ ether extract; soyhulls $=10.9 \% \mathrm{CP}, 67.4 \% \mathrm{NDF}, 48.7 \% \mathrm{ADF}$, and $1.1 \%$ ether extract.

${ }^{2}$ Megalac, Church and Dwight Co., Inc., Princeton, NJ.

${ }^{3}$ Vitamins and minerals contained $0.6 \% \mathrm{CaCO}_{3}, 0.06 \% \mathrm{MgO}, 0.008 \%$ Se Premix, $0.025 \%$ vitamin E, $1.6 \%$ 15-5 Dairy Mineral premix (Nutreco Canada Inc., Guelph, Canada).

${ }^{4}$ Net energy of lactation calculated using a daily DMI of $24.0 \mathrm{~kg}$ (NRC, 2001). 
weighed, and then the content of each bag was removed and individually stored into glass vial until analysis.

\section{Chemical Analyses}

Feed ingredients were analyzed for $\mathrm{CP}(\mathrm{N} \times 6.25)$ by combustion (Dumas Method, Leco Corporation, St. Joseph, MI). Ether extract was determined using an Ankom extractor (Ankom Technology, Macedon, NY) with petroleum ether as the solvent. Analyses of NDF and ADF were performed according to the methods of Van Soest et al. (1991) using an Ankom fiber analyzer (Ankom Technology) with heat-stable $\alpha$-amylase and without sodium sulfite. Starch concentration was measured by enzymatic method (Holm et al., 1996). Soluble proteins, neutral detergent insoluble CP (NDICP), and acid detergent insoluble CP (ADICP) were determined according to the procedures of Licitra et al. (1996).

A subsample of the content of each bag was individually analyzed for N (Dumas Method, Rapid N Cube, Elementar Analysensystem GmbH, Hanau, Germany) and $\mathrm{CP}$ was calculated as $\mathrm{N} \times 6.25$. Then, the remaining contents of the $0-\mathrm{h}$ and $16-\mathrm{h}$ bags were pooled by cow and time before being ground (0.5-mm screen) for AA analysis. The AA composition was determined by isotopic dilution after a 24 -h acid-hydrolysis ( $6 \mathrm{~N}$ phenol- $\mathrm{HCl}$ ) at $110^{\circ} \mathrm{C}$, with a separate sample subjected to performic acid oxidation before hydrolysis for Met, as described by Borucki Castro et al. (2007). Samples were analyzed in triplicate.

\section{Determination of Small Particle Loss from Nylon Bags}

The procedure for determining small particle loss from nylon bags was derived from Hvelplund and Weisbjerg (2000). Each protein supplement was milled through a $2.0-\mathrm{mm}$ screen. Subsamples were weighed $(1 \mathrm{~g})$ in triplicate into $250-\mathrm{mL}$ beakers and $40 \mathrm{~mL}$ of distilled water was added. The beakers were incubated for $1 \mathrm{~h}$ at room temperature with manual stirring every 15 min. After incubation, samples were washed 2 times with $20 \mathrm{~mL}$ of distilled water through filter paper (no. 41, Whatman, Springfield Mill, Maidstone, UK). The residue on the filter paper was dried at $55^{\circ} \mathrm{C}$ for 24 $\mathrm{h}$ and used for $\mathrm{N}$ analysis (Rapid $\mathrm{N}$ cube, Elementar Analysensystem $\mathrm{GmbH}$ ).

\section{Calculations}

Data from rumen-undegraded residues were corrected or not for small particle loss according to Hvelplund and Weisbjerg (2000) calculations. Rumen degradability of
DM and CP was calculated, both from corrected or uncorrected data, according to the model without lag time of Ørskov and McDonald (1979) and the model with lag time of Denham et al. (1989).

Without lag time,

$$
D=a+b \times\left(1-e^{-c \times t}\right),
$$

and with lag time,

$$
\begin{gathered}
D=a, \text { for } t \leq L \\
D=a+b \times\left[1-e^{-c \times(t-L)}\right], \text { for } t>L,
\end{gathered}
$$

where $D$ is the degradation after $t$ hours of rumen incubation; $a$ is the water-soluble and rapidly degradable fraction; $b$ is the insoluble but degradable fraction; $c$ is the degradation rate of fraction $b$; and $L$ the time lag before the beginning of degradation of $b$. The nonlinear procedure (PROC NLIN) of SAS (SAS Institute, 2001) was used to fit degradation data to the models and the model yielding the minimal sum of squares was retained as a better fit to the data set. The effective degradability (ED) in the rumen was calculated from the equation of Denham et al. (1989):

$$
\mathrm{ED}=a+[b \times c /(c+k)] \times e^{-k \times t},
$$

where $a$ is the water-soluble and rapidly degradable fraction; $b$ is the insoluble but degradable fraction; $c$ is the degradation rate of fraction $b$; and $k$ the rumen passage rate. Passage rate was calculated at $0.074 \mathrm{~h}^{-1}$ from the equation developed by NRC (2001) for concentrates.

\section{Statistical Analyses}

Predicted values for $a, b, c, L$, and ED, the percentage of AA disappearance after $16 \mathrm{~h}$ of ruminal incubation, the AA content in the bags residues, and the 16- $\mathrm{h}$ residue AA composition to original feed AA composition ratio were analyzed using randomized complete block design with the MIXED procedure of SAS (SAS Institute, 2001). The model used for analyses was

$$
Y_{i j}=\mu+F_{i}+c_{j}+e_{i j}
$$

where $Y_{i j}$ is the value of the variable studied on the $i$ th protein supplement for the $j$ th cow; $\mu$ is the overall mean; $F_{i}$ is the fixed effects of $i$ th protein supplement ( $i$ $=1$ to 4$) ; c_{j}$ is the random effect of $j$ th cow $(j=1$ to 4$)$; and $e_{i j}$ is random error. Multiple comparisons of means were performed using the adjusted Tukey-Kramer test. 


\section{RESULTS AND DISCUSSION}

\section{Feed Chemical Composition}

The chemical composition of the protein supplements is presented in Table 2. The SBM had the greatest CP concentration (53.6 vs. $40 \%$ for the other ingredients). These CP concentrations are comparable with published values (NRC, 2001; Robinson et al., 2008; FOBI Network, 2011). The NDF and ADF concentrations for SBM and the DDG were within expected ranges reported in literature (Borucki Castro et al., 2007; Mjoun et al., 2010; Li et al., 2012). However, NDF and $\mathrm{ADF}$ concentrations for $\mathrm{CM}$ were high (31.9 and $22.5 \%$ for NDF and ADF, respectively) and close to values measured for the high fiber fraction obtained from tailend dehulling of regular CM (Mustafa et al., 1996). The ether extract concentration varied between protein sources from $1.5 \%$ for SBM to 5.6\% for WDDGS.

Protein fractions differed between protein supplements. The HPDDG had the lowest soluble protein proportion (12.0\% of CP vs. an average of $28.6 \%$ of CP for the others supplements). This compares with values previously reported for HPDDG (Hubbard et al., 2009; Kelzer et al., 2010) and is possibly explained by the fractionation process used to remove solubles (Robin- son et al., 2008). The NDICP (\% of CP) varied from $4.0 \%$ for SBM to $16.7 \%$ for CM and ADICP (\% of CP) from $1.5 \%$ for SBM to $9.5 \%$ for the DDG. The high values for CM agree with those obtained with NDF and ADF concentrations, given that NDICP and ADICP are associated with NDF and ADF concentrations. High NDICP proportion could reflect higher slowly degradable protein fraction in the rumen (Mustafa et al., 2000). High ADICP values for the DDG may result from heat treatment during the drying step (ADICP being an indicator of heat-damaged protein) and could lead to reduced protein digestibility. However, ADICP values up to $13.2 \%$ (Mjoun et al., 2010) and up to $11.9 \%$ (Kleinschmit et al., 2007) for DDG have been shown to have no detrimental effect on protein digestibility.

The AA profiles were differed among protein supplements. The Lys concentration was lower for DDG $(2.6 \%$ of $\mathrm{CP}$ on average) than for SBM and CM (5.4\% of CP on average). Soybean meal had the lowest concentration in Met (1.55 vs. $2.23 \%$ of $\mathrm{CP}$ on average for the other feeds) and WDDGS had the lowest content in His (2.21 vs. $2.54 \%$ of CP for the other feeds). The AA profile of SBM and CM was within expected ranges observed in literature (NRC, 2001; Oba et al., 2010; Heendeniya et al., 2012), even if the Lys concentrations were slightly

Table 2. Chemical and AA composition of the 4 protein supplements

\begin{tabular}{|c|c|c|c|c|}
\hline \multirow[b]{2}{*}{ Item $^{1}$} & \multicolumn{4}{|c|}{ Protein supplement ${ }^{2}$} \\
\hline & SBM & $\mathrm{CM}$ & HPDDG & WDDGS \\
\hline $\mathrm{CP}, \%$ of DM & 53.6 & 40.1 & 40.3 & 37.2 \\
\hline Soluble CP, $\%$ of CP & 31.0 & 25.3 & 12.0 & 29.5 \\
\hline NDICP, $\%$ of $\mathrm{CP}$ & 4.0 & 16.7 & 8.8 & 9.1 \\
\hline ADICP, $\%$ of CP & 1.5 & 7.7 & 10.1 & 8.8 \\
\hline NDF, \% of DM & 9.5 & 31.9 & 26.2 & 27.9 \\
\hline $\mathrm{ADF}, \%$ of DM & 6.4 & 22.5 & 13.5 & 14.6 \\
\hline Ether extract, $\%$ of DM & 1.5 & 3.6 & 4.0 & 5.6 \\
\hline Starch, \% of DM & 1.5 & 1.6 & 7.0 & 3.4 \\
\hline Ash, \% of DM & 6.9 & 8.0 & 3.5 & 6.2 \\
\hline \multicolumn{5}{|l|}{ Essential AA, $\%$ of $\mathrm{CP}$} \\
\hline His & 2.55 & 2.54 & 2.53 & 2.21 \\
\hline Ile & 3.89 & 3.72 & 3.77 & 3.61 \\
\hline Leu & 7.52 & 6.78 & 12.83 & 7.27 \\
\hline Lys & 5.91 & 4.88 & 2.72 & 2.53 \\
\hline Met & 1.55 & 2.32 & 2.26 & 2.10 \\
\hline Phe & 5.02 & 3.95 & 5.17 & 4.77 \\
\hline Thr & 4.07 & 4.40 & 3.81 & 3.37 \\
\hline Val & 3.76 & 4.35 & 4.26 & 4.07 \\
\hline Total essential AA & 34.27 & 32.94 & 37.35 & 29.93 \\
\hline \multicolumn{5}{|l|}{ Nonessential AA, $\%$ of CP } \\
\hline Ala & 4.26 & 4.27 & 7.29 & 4.26 \\
\hline Gly & 4.21 & 4.90 & 3.31 & 4.15 \\
\hline Pro & 5.07 & 5.89 & 8.40 & 9.65 \\
\hline Ser & 5.44 & 4.25 & 4.93 & 4.83 \\
\hline Tyr & 3.66 & 3.02 & 4.47 & 3.36 \\
\hline Total nonessential AA & 22.64 & 23.33 & 28.40 & 26.25 \\
\hline
\end{tabular}

${ }^{1} \mathrm{NDICP}=$ neutral detergent insoluble $\mathrm{CP}$; ADICP $=$ acid detergent insoluble $\mathrm{CP}$.

${ }^{2} \mathrm{SBM}=$ soybean meal; $\mathrm{CM}=$ canola meal; HPDDG $=$ high-protein corn dried distillers grains and solubles; WDDGS $=$ wheat dried distillers grains and solubles . 
lower than values reported in NRC (2001; 5.91 vs. $6.29 \%$ for SBM; 4.88 vs. $5.62 \%$ for CM, respectively) and Met concentrations were slightly higher (1.55 vs. 1.44 for SBM; $2.32 \%$ vs. $1.87 \%$ for CM). The AA profiles of DDG are comparable with profiles published for HPDDG (Mjoun et al., 2010; Li et al., 2012) and for WDDGS (Abdelqader and Oba, 2012; Li et al., 2012). The most noticeable differences among AA between HPDDG and WDDGS were higher concentrations of Ala, Leu, and Tyr in HPDDG and higher concentrations of Gly and Pro in WDDGS. These differences could be linked to the original AA profile of wheat and corn grains (Li et al., 2012).

\section{Rumen Degradation Kinetics}

Small particle loss contributed to the disappearance of DM and CP from the rumen bags. This disappearance was more than 2 times higher for WDDGS (31.6\% of DM and $45.7 \%$ of CP feed) than for the other protein supplements $(11.3,14.7$, and $17.3 \%$ of DM and 16.3 , 19.7, and $18.9 \%$ of CP for SBM, CM and HPDDG, respectively). Small particle loss might be partially due to sample preparation, more specifically to grinding, and can result in an overestimation of ruminal degradation (Michalet-Doreau and Ould-Bah, 1992). The grinding of WDDGS pellets may have released small particles coming from the WDDGS production process. The drygrinding step of the process would cause fracture of the seed kernels, leaving protein as a fine powder. Indeed, Michalet-Doreau and Ould-Bah (1992), Prestløkken (1999) and Hvelplund and Weisbjerg (2000) previously observed that particle loss was high for some grains, such as barley or oats, in comparison with SBM, rapeseed meal, or maize grain. Thus, the correction for the small particle loss would be relevant when comparing these feed ingredients. Correction for small particle loss resulted in decreased water-soluble and rapidly degradable fraction (fraction $a$ ) and increased insoluble but degradable fraction (fraction $b$; Table 3) of both DM and $\mathrm{CP}$ components. Thus, the uncorrected ED values were higher than the corrected ED values for all feeds, but importantly similar pattern between protein supplements was observed for both parameters.

The ED of DM and CP were higher for WDDGS and SBM than for CM and HPDDG (Table 3). For WDDGS, the high ED was mainly due to a high soluble fraction $\left[a\right.$ corrected $\left(\boldsymbol{a}_{\text {cor }}\right)=33.3 \%$ of DM and $27.6 \%$ of CP vs. 21.3 and $13.4 \%$ of DM, 12.9 and $2.0 \%$ of $\mathrm{CP}$ for $\mathrm{CM}$ and HPDDG, respectively]. The higher ED for SBM was due to a combination of high insoluble but degradable fraction and high rate of degradation in SBM (0.09 vs. $0.054 \mathrm{~h}^{-1}$, on average, for CM and HPDDG). The soluble fraction in SBM was also high for DM $\left(a_{\text {cor }}=30.1 \%\right.$ of DM). The corrected ED values estimated for SBM (67.5\% for DM and $58.5 \%$ for CP) were comparable to published values. Heendeniya et al. (2012) reported ED of DM to be $64.5 \%$ and ED of CP to be $54.7 \%$ without correction for small particle loss; Borucki Castro et al. (2007) and Harstad and Prestløkken (2000) observed ED of CP values of 58.3 and $52.2 \%$, respectively, with corrected data. In contrast, the corrected $\mathrm{ED}$ values estimated for $\mathrm{CM}$ in the current study ( $47.5 \%$ for DM and $47.5 \%$ for CP) were lower than values usually reported in the literature. Numerous authors observed higher ED values, between 58 and $76 \%$ for ED of DM and between 60 and $80 \%$ for ED of CP (e.g., Mustafa et al., 1996; Piepenbrink and Schingoethe, 1998; Heendeniya et al., 2012), mainly due to higher values of soluble fraction and rate of degradation compared with our study. However, none of these authors corrected data for particle loss, which could explain the difference in ED. In the current experiment, CM had lower CP degradability than SBM. This is in contrast to most feed tables (AFRC 1993; INRA, 2007; NorFor, 2010), which report SBM to have a greater metabolizable protein value than $\mathrm{CM}$ on a $\mathrm{CP}$ basis because of a lower CP degradability. However, 2 recent meta-analyses (Huhtanen et al., 2011; Martineau et al., 2013) comparing SBM and CM suggested that the current feed evaluation systems could underestimate metabolizable protein supply with CM diets.

The HPDDG was the lowest degradable protein source due to a low soluble fraction $\left(a_{\text {cor }}=13.4 \%\right.$ for DM and $2.0 \%$ for CP) and a high insoluble but degradable fraction $\left[b\right.$ corrected $\left(\boldsymbol{b}_{\text {cor }}\right)=79.3 \%$ for DM and $93.2 \%$ for CP]. These values observed for $a_{\text {cor }}, b_{\text {cor }}$, and corrected $\mathrm{ED}$ of $\mathrm{CP}$ are consistent with values reported for HPDDG in 2 recent experiments (Mjoun et al., 2010; Li et al., 2012), although the authors did not correct data for particle loss. Due to the production process, proteins in HPDDG mainly come from endosperm, which is composed of corn zein protein known to be insoluble and resistant to ruminal degradation (Little et al., 1968). The corrected ED of DM estimated for WDDGS (53.2\%) are similar to uncorrected ED of DM reported by Nuez-Ortín and Yu (2010) and Li et al. (2012), even if these authors obtained higher values for the insoluble but degradable fraction and slightly lower rate of degradation than the values of the current study. The corrected ED of CP values (60.8\%) are higher than values observed in literature, between 41 and 49\% (Boila and Ingalls, 1994b; Li et al., 2012; Zhang and $\mathrm{Yu}, 2012)$. These authors reported higher insoluble but degradable fraction $(73.5 \%$ on average vs. $57.4 \%$ in the present study) and lower rate of degradation $\left(0.035 \mathrm{~h}^{-1}\right.$ on average vs. $0.11 \mathrm{~h}^{-1}$ in the present study) although the particle loss was not considered 
Table 3. Rumen degradation parameters and effective degradability of DM and CP for the 4 protein supplements

\begin{tabular}{|c|c|c|c|c|c|c|}
\hline \multirow[b]{2}{*}{ Item $^{1}$} & \multicolumn{4}{|c|}{ Protein supplement ${ }^{2}$} & \multirow[b]{2}{*}{ SEM } & \multirow[b]{2}{*}{$P$-value ${ }^{3}$} \\
\hline & SBM & $\mathrm{CM}$ & HPDDG & WDDGS & & \\
\hline \multicolumn{7}{|c|}{ Uncorrected for particle loss } \\
\hline \multicolumn{7}{|c|}{$\mathrm{DM}$} \\
\hline$a, \%$ & $41.0^{\mathrm{b}}$ & $35.9^{\mathrm{c}}$ & $30.7^{\mathrm{d}}$ & $64.3^{\mathrm{a}}$ & 0.59 & 0.001 \\
\hline$b, \%$ & $59.0^{\mathrm{b}}$ & $48.4^{\mathrm{c}}$ & $63.5^{\mathrm{a}}$ & $22.7^{\mathrm{d}}$ & 0.88 & 0.001 \\
\hline$c, \mathrm{~h}^{-1}$ & $0.09^{\mathrm{a}}$ & $0.06^{\mathrm{b}}$ & $0.05^{\mathrm{b}}$ & $0.07^{\mathrm{ab}}$ & 0.006 & 0.01 \\
\hline$L, \mathrm{~h}$ & 1.7 & 0.5 & 0.4 & 0.3 & 0.46 & 0.17 \\
\hline $\mathrm{ED}, \%$ & $72.6^{\mathrm{a}}$ & $57.2^{\mathrm{b}}$ & $55.5^{\mathrm{b}}$ & $75.0^{\mathrm{a}}$ & 1.11 & 0.001 \\
\hline \multicolumn{7}{|l|}{$\mathrm{CP}$} \\
\hline$a, \%$ & $27.7^{\mathrm{c}}$ & $32.4^{\mathrm{b}}$ & $20.5^{\mathrm{d}}$ & $72.1^{\mathrm{a}}$ & 0.74 & 0.001 \\
\hline$b, \%$ & $72.3^{\mathrm{a}}$ & $62.2^{\mathrm{b}}$ & $75.8^{\mathrm{a}}$ & $22.3^{\mathrm{c}}$ & 2.10 & 0.001 \\
\hline$c, \mathrm{~h}^{-1}$ & $0.09^{\mathrm{ab}}$ & $0.06^{\mathrm{bc}}$ & $0.04^{\mathrm{c}}$ & $0.10^{\mathrm{a}}$ & 0.010 & 0.009 \\
\hline$L, \mathrm{~h}$ & 1.0 & 0.1 & 1.5 & 0.5 & 0.48 & 0.19 \\
\hline $\mathrm{ED}, \%$ & $66.0^{\mathrm{b}}$ & $59.3^{\mathrm{c}}$ & $48.2^{\mathrm{d}}$ & $84.8^{\mathrm{a}}$ & 1.64 & 0.001 \\
\hline \multicolumn{7}{|c|}{ Corrected for particle loss ${ }^{4}$} \\
\hline \multicolumn{7}{|c|}{$\mathrm{DM}$} \\
\hline$a_{\text {cor }}, \%$ & $30.1^{\mathrm{a}}$ & $21.3^{\mathrm{b}}$ & $13.4^{\mathrm{c}}$ & $33.3^{\mathrm{a}}$ & 0.74 & 0.001 \\
\hline$b_{\text {cor }}, \%$ & $69.9^{\mathrm{b}}$ & $59.4^{\mathrm{c}}$ & $79.3^{\mathrm{a}}$ & $42.3^{\mathrm{d}}$ & 1.21 & 0.001 \\
\hline$c, \mathrm{~h}^{-1}$ & $0.09^{\mathrm{a}}$ & $0.06^{\mathrm{b}}$ & $0.05^{\mathrm{b}}$ & $0.07^{\mathrm{ab}}$ & 0.009 & 0.01 \\
\hline$L, \mathrm{~h}$ & 1.7 & 0.5 & 0.4 & 0.3 & 0.48 & 0.17 \\
\hline $\mathrm{ED}_{\text {cor }}, \%$ & $67.5^{\mathrm{a}}$ & $47.5^{\mathrm{c}}$ & $44.5^{\mathrm{c}}$ & $53.2^{\mathrm{b}}$ & 1.36 & \\
\hline \multicolumn{7}{|l|}{$\mathrm{CP}$} \\
\hline$a_{\mathrm{cor}}, \%$ & $11.8^{\mathrm{b}}$ & $12.9^{\mathrm{b}}$ & $2.0^{\mathrm{c}}$ & $27.6^{\mathrm{a}}$ & 1.07 & 0.001 \\
\hline$b_{\text {cor }}, \%$ & $88.3^{\mathrm{ab}}$ & $80.1^{\mathrm{b}}$ & $93.2^{\mathrm{a}}$ & $57.4^{\mathrm{c}}$ & 2.91 & 0.001 \\
\hline$c, \mathrm{~h}^{-1}$ & $0.09^{\mathrm{ab}}$ & $0.06^{\mathrm{bc}}$ & $0.04^{\mathrm{c}}$ & $0.11^{\mathrm{a}}$ & 0.010 & 0.009 \\
\hline$L, \mathrm{~h}$ & 1.0 & 0.1 & 1.7 & 0.7 & 0.58 & 0.27 \\
\hline $\mathrm{ED}_{\mathrm{cor}}, \%$ & $58.5^{\mathrm{a}}$ & $47.5^{\mathrm{b}}$ & $36.4^{\mathrm{c}}$ & $60.8^{\mathrm{a}}$ & 2.22 & 0.001 \\
\hline $\mathrm{RUP}^{5} \%$ & $41.5^{\mathrm{c}}$ & $52.5^{\mathrm{b}}$ & $63.6^{\mathrm{a}}$ & $39.2^{\mathrm{c}}$ & 2.23 & 0.001 \\
\hline
\end{tabular}

${ }^{\mathrm{a}-\mathrm{d}}$ Values in the same row with a different superscript are different $(P<0.05)$.

${ }^{1}$ Rumen parameters: $a=$ water-soluble and rapidly degradable fraction; $b=$ insoluble but degradable fraction; $c=$ degradation rate of fraction $b$ and $L$ the time lag before the beginning of degradation of $b$; ED $=$ effective degradability calculated with a passage rate of $0.074 \mathrm{~h}^{-1}$; cor $=$ corrected for small particle loss.

${ }^{2} \mathrm{SBM}=$ soybean meal; $\mathrm{CM}=$ canola meal; HPDDG $=$ high protein corn dried distillers grains; WDDGS = wheat dried distillers grains and solubles.

${ }^{3}$ Probability corresponding to the null hypothesis.

${ }^{4}$ According to Hvelplund and Weisbjerg (2000).

${ }^{5} \mathrm{RUP}=b[k /(k+c)]$, where $b$ is the insoluble but degradable fraction, $c$ is the degradation rate of fraction $b$, and $k$ is the rate of passage from the rumen estimated at $0.074 \mathrm{~h}^{-1}$.

in these studies. In contrast, Li et al. (2011) observed uncorrected ED of CP values between 71.2 and $75.1 \%$. The discrepancy between studies could be explained by variability in the original grain composition or in production process (drying step, breakdown of protein during fermentation, addition of solubles), which could induce greater particle loss. Finally, the RUP values averaged $39.2,41.5,52.5$, and $63.6 \%$ for WDDGS, SBM, $\mathrm{CM}$, and HPDDG, respectively.

\section{AA Disappearance and RUP Composition}

The ruminal disappearance of essential AA and total AA reflected the overall pattern of $\mathrm{CP}$ degradation between protein supplements (Table 4), as the ruminal disappearance of AA was higher for SBM and WDDGS than for CM and HPDDG. Overall, Lys, His, and Pro were the most degraded AA. According to Gerrard (2002), Lys and His are very reactive AA and, therefore, more sensitive to degradation. Except for CM, Met and Leu were the least degraded essential AA in the protein supplements and the level of disappearance of these 2 AA after washing (0-h ruminal incubation) was low, suggesting that these AA were less soluble.

The ruminal disappearance of individual AA differed between the $2 \mathrm{DDG}$, in agreement with the observation by Li et al. (2012). The most degradable AA were His, Lys, and Val for HPDDG and His, Gly, and Pro for WDDGS, whereas the least degradable were Ala, Leu, and Met for both DDG; these findings are consistent with those observed by Mjoun et al. (2010) for HPDDG and Boila and Ingalls (1994a) for WDDGS. Values for SBM showed that His and Lys were the most degraded AA, whereas Met and the branched-chain essential AA were the least degraded; these findings agree with those of Borucki Castro et al. (2007) and Mjoun et al. (2010). For CM, the most degraded AA were Lys and Pro, and the least degraded were Phe, Ser, Thr and Tyr; these 
Table 4. Crude protein and AA disappearance (\% of original feed) from the 4 protein supplements after 0 or $16 \mathrm{~h}$ of ruminal incubation

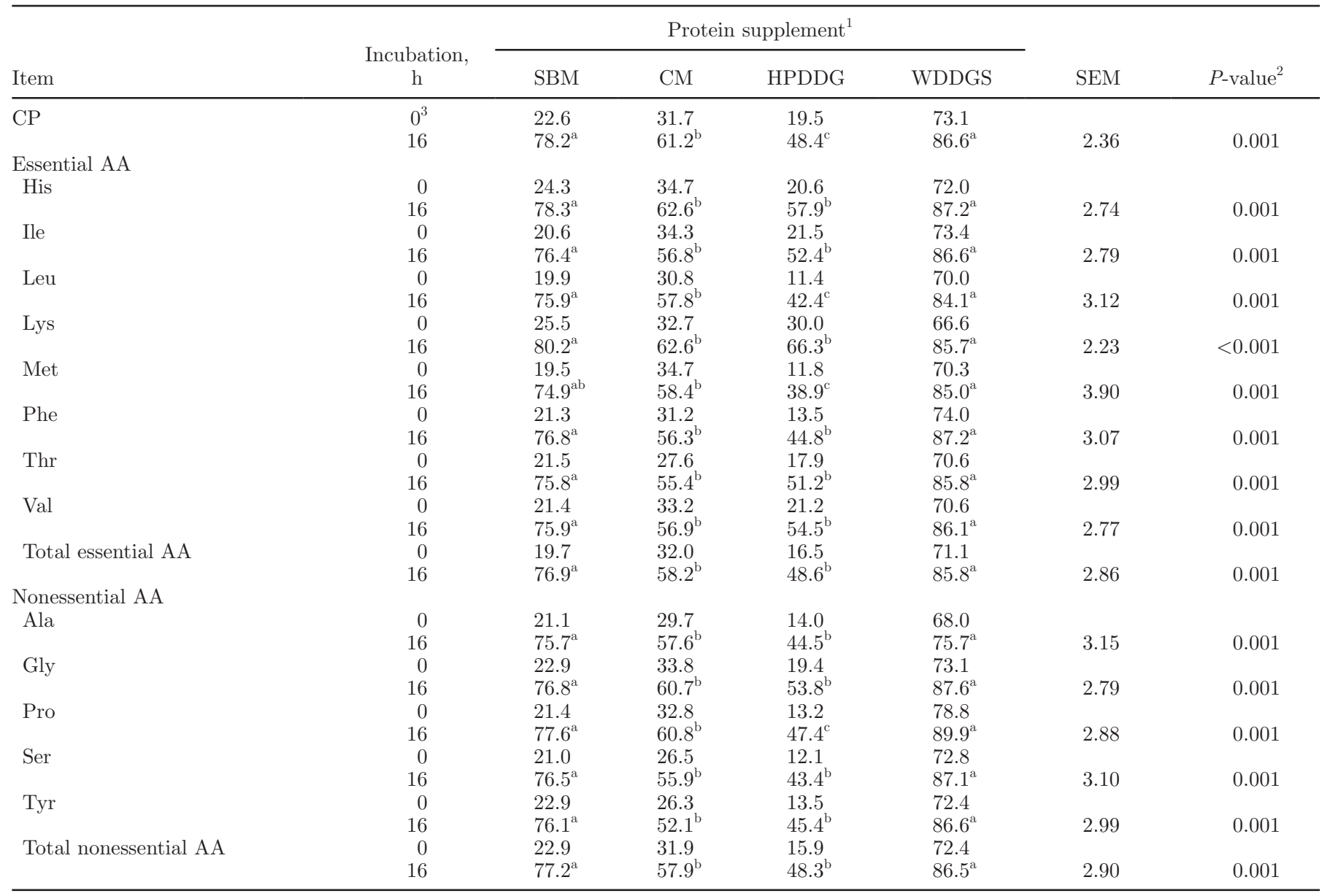

${ }^{\mathrm{a} c \mathrm{c}}$ Values in the same row with a different superscript are different $(P<0.05)$.

${ }^{1}$ Protein supplement: $\mathrm{SBM}=$ soybean meal; $\mathrm{CM}=$ canola meal; HPDDG $=$ high protein corn dried distillers grains; WDDGS $=$ wheat dried distillers grains and solubles.

${ }^{2}$ Probability corresponding to the null hypothesis.

${ }^{3} 0 \mathrm{~h}$ : proportion of AA that disappeared after washing, 1 pooled sample per protein supplements.

results are consistent with those reported by Harstad and Prestløkken (2001) and Boila and Ingalls (1994a). According to van Straalen et al. (1997), the difference in the degradation rates of individual AA between protein supplements may be related to the content of the different protein classes in the feedstuff, their physical properties, and AA composition.

The AA composition of the protein supplements remaining after $16 \mathrm{~h}$ of ruminal incubation and the 16-h AA concentration to original feed AA concentration ratio are presented in Table 5. Ruminal incubation lowered concentrations of His and Lys in most protein supplements, consistent with the higher ruminal disappearance observed for these $2 \mathrm{AA}$. The concentrations of most of the other essential AA increased for all protein supplements $(16 \mathrm{~h}$-to-original feed ratio $>1)$. The concentrations of most nonessential AA increased or remained constant after $16 \mathrm{~h}$ of ruminal incubation for SBM, CM, and HPDDG, whereas it decreased for WDDGS.

The HPDDG and WDDGS residues had the lowest concentrations in His and Lys (2.05 and $1.76 \%$ for HPDDG and 2.10 and $2.68 \%$ for WDDGS, respectively), whereas the SBM residue had the lowest concentrations in Met. Although HPDDG is a good source of RUP, the low 16 h-to-original feed ratio for Lys $(0.65)$ and His (0.81) suggests that the protein quality of RUP for HPDDG decreased compared with its original feed protein composition. This variation in the AA profile from original feed emphasizes the importance of the in situ approach to estimate the AA profile of the undegraded protein (Gonzalez et al., 2001) and indicates that the feed AA profile needs to be adjusted to account for differential rumen degradation. This will be particularly important in factorial models requiring AA composition of the different protein fractions contributing to protein 
Table 5. Amino acid composition of the 4 protein supplements residues after $16 \mathrm{~h}$ of ruminal incubation (\% of $\mathrm{CP})$ and the ratio 16 -h AA concentration to original feed AA concentration (ratio)

\begin{tabular}{|c|c|c|c|c|c|c|c|}
\hline \multirow[b]{2}{*}{ Item } & \multirow[b]{2}{*}{ Subset } & \multicolumn{4}{|c|}{ Protein supplement ${ }^{1}$} & \multirow[b]{2}{*}{ SEM } & \multirow[b]{2}{*}{$P$-value ${ }^{2}$} \\
\hline & & SBM & $\mathrm{CM}$ & HPDDG & WDDGS & & \\
\hline His & Ratio $^{3}$ & $0.99^{\mathrm{a}}$ & $0.96^{\mathrm{a}}$ & $0.81^{\mathrm{b} *}$ & $0.95^{\mathrm{a}}$ & 0.025 & 0.024 \\
\hline \multirow[t]{2}{*}{ Ile } & $\%$ of $\mathrm{CP}$ & $4.21^{\mathrm{a}}$ & $4.13^{\mathrm{a}}$ & $3.47^{\mathrm{b}}$ & $3.61^{\mathrm{b}}$ & 0.097 & 0.006 \\
\hline & Ratio & $1.08^{\mathrm{ab} *}$ & $1.11^{\mathrm{a} *}$ & $0.92^{\mathrm{c} *}$ & $1.00^{\mathrm{bc}}$ & 0.025 & 0.016 \\
\hline \multirow[t]{2}{*}{ Lys } & $\%$ of $\mathrm{CP}$ & $5.40^{\mathrm{a}}$ & $4.69^{\mathrm{b}}$ & $1.76^{\mathrm{d}}$ & $2.68^{\mathrm{c}}$ & 0.076 & 0.001 \\
\hline & Ratio & $0.91^{\mathrm{b} *}$ & $0.85^{\mathrm{b} *}$ & $0.65^{\mathrm{c} *}$ & $1.06^{\mathrm{a} *}$ & 0.022 & 0.001 \\
\hline \multirow[t]{2}{*}{ Met } & $\%$ of $\mathrm{CP}$ & $1.79^{\mathrm{b}}$ & $2.47^{\mathrm{a}}$ & $2.67^{\mathrm{a}}$ & $2.34^{\mathrm{a}}$ & 0.124 & $<0.001$ \\
\hline & Ratio & 1.04 & 1.07 & $1.18^{*}$ & 1.11 & 0.055 & 0.08 \\
\hline \multirow[t]{2}{*}{ Phe } & $\%$ of $\mathrm{CP}$ & $5.34^{\mathrm{a}}$ & $4.45^{\mathrm{b}}$ & $5.51^{\mathrm{a}}$ & $4.52^{\mathrm{b}}$ & 0.115 & 0.002 \\
\hline & Ratio & $1.06^{\mathrm{a} *}$ & $1.12^{\mathrm{a} *}$ & $1.06^{\mathrm{a} *}$ & $0.95^{\mathrm{b}}$ & 0.024 & 0.003 \\
\hline Thr & $\%$ of $\mathrm{CP}$ & $4.50^{\mathrm{b}}$ & $5.04^{\mathrm{a}}$ & $3.58^{\mathrm{c}}$ & $3.53^{\mathrm{c}}$ & 0.088 & 0.001 \\
\hline \multicolumn{8}{|l|}{ Nonessential AA } \\
\hline \multirow[t]{2}{*}{ Ala } & $\%$ of $\mathrm{CP}$ & $4.75^{\mathrm{b}}$ & $4.66^{\mathrm{b}}$ & $7.80^{\mathrm{a}}$ & $5.15^{\mathrm{b}}$ & 0.145 & 0.001 \\
\hline & Ratio & $1.11^{\mathrm{ab} *}$ & $1.09^{\mathrm{b} *}$ & $1.07^{\mathrm{b} *}$ & $1.21^{\mathrm{a} *}$ & 0.025 & 0.011 \\
\hline \multirow[t]{2}{*}{ Gly } & $\%$ of $\mathrm{CP}$ & $4.49^{\mathrm{b}}$ & $4.96^{\mathrm{a}}$ & $2.85^{\mathrm{d}}$ & $4.01^{\mathrm{c}}$ & 0.086 & 0.001 \\
\hline & Ratio & $1.02^{\mathrm{a}}$ & $1.01^{\mathrm{a}}$ & $0.86^{\text {a* }}$ & $0.97^{\mathrm{b}}$ & 0.023 & 0.003 \\
\hline \multirow[t]{2}{*}{ Pro } & $\%$ of $\mathrm{CP}$ & $5.22^{\mathrm{d}}$ & $5.96^{\mathrm{c}}$ & $8.53^{\mathrm{a}}$ & $7.25^{\mathrm{b}}$ & 0.161 & 0.001 \\
\hline & Ratio & $1.03^{\mathrm{a}}$ & $1.01^{\mathrm{a}}$ & $1.01^{\mathrm{a}}$ & $0.75^{\mathrm{b} *}$ & 0.019 & 0.001 \\
\hline \multirow[t]{2}{*}{ Ser } & $\%$ of $\mathrm{CP}$ & $5.87^{\mathrm{a}}$ & $4.82^{\mathrm{bc}}$ & $5.21^{\mathrm{b}}$ & $4.63^{\mathrm{c}}$ & 0.119 & 0.002 \\
\hline & Ratio & $1.08^{\mathrm{a} *}$ & $1.13^{\mathrm{a} *}$ & $1.05^{\mathrm{ab}}$ & $0.96^{\mathrm{b}}$ & 0.025 & 0.005 \\
\hline \multirow[t]{2}{*}{ Tyr } & $\%$ of $\mathrm{CP}$ & $4.00^{\mathrm{b}}$ & $3.72^{\mathrm{b}}$ & $4.71^{\mathrm{a}}$ & $3.35^{\mathrm{c}}$ & 0.084 & 0.001 \\
\hline & Ratio & $1.09^{\mathrm{b} *}$ & $1.23^{\mathrm{a} *}$ & $1.06^{\mathrm{b} *}$ & $0.99^{\mathrm{b}}$ & 0.022 & 0.001 \\
\hline \multirow[t]{2}{*}{ Total nonessential AA } & $\%$ of $\mathrm{CP}$ & $24.34^{\mathrm{b}}$ & $24.12^{\mathrm{b}}$ & $29.10^{\mathrm{a}}$ & $24.39^{\mathrm{b}}$ & 0.583 & 0.005 \\
\hline & Ratio & 1.04 & 1.04 & 1.00 & 0.98 & 0.038 & 0.63 \\
\hline
\end{tabular}

${ }^{\mathrm{a}-\mathrm{d}}$ Values in the same row with a different superscript are different $(P<0.05)$.

${ }^{1} \mathrm{SBM}=$ soybean meal; $\mathrm{CM}=$ canola meal; HPDDG = high protein corn dried distillers grains; WDDGS = wheat dried distillers grains and solubles.

${ }^{2}$ Probability corresponding to the null hypothesis.

${ }^{*} P<0.05$; indicates that the ratio is different from 1 .

duodenal flow, including the RUP fraction. Moreover, because Lys digestibility might be lower in DDG than in SBM due to heat generated during process (Boucher et al., 2009), Lys would be the most altered AA with HPDDG and WDDGS diets, but His availability should also be carefully evaluated. Even if Met was the least degraded AA in SBM, its concentration in RUP was low, confirming that SBM-based diets might be a limited source of Met (Illg et al., 1987; Chen et al., 2011). In the current study, CM presented a high RUP value, had the lowest AA concentrations in RUP for Leu and Phe, but had the second highest residues concentrations for Met, Lys, and His as compared with the 3 others protein supplements.

\section{CONCLUSIONS}

This study suggests that correction of rumen degradability for small particle loss is relevant when compar- ing $\mathrm{CM}$ and DDG, not taking into account that loss could be misleading on the supply of either RDP or RUP. The particle loss correction, however, did not alter feed ranking for DM and CP ruminal degradation; SBM and WDDGS were more degradable than CM and HPDDG. Ruminal AA disappearance varied between individual AA and protein supplements; therefore, AA composition of the RUP fraction, rather than the feed ingredient, could improve the prediction of the digestive flow of AA, especially for HPDDG.

\section{ACKNOWLEDGMENTS}

The authors are grateful to D. Bournival, J. Renaud, and M. Leonard (Agriculture and Agri-Food Canada) for their dedicated technical assistance, S. Methot for statistical analyses (Agriculture and Agri-Food Canada), and the staff of the Dairy Centre for care of the 
animals. The funding support of the Canola Council of Canada (Winnipeg, MB, Canada) and Agriculture and Agri-Food Canada is gratefully acknowledged.

\section{REFERENCES}

Abdelqader, M. M., and M. Oba. 2012. Lactation performance of dairy cows fed increasing concentrations of wheat dried distillers grains with solubles. J. Dairy Sci. 95:3894-3904.

AFRC (Agricultural and Food Research Council). 1993. Energy and Protein Requirements of Ruminants. CAB International, Wallingford, UK.

Bell, J. M. 1984. Nutrients and toxicants in rapeseed meal: A review. J. Anim. Sci. 58:996-1010.

Boila, R. J., and J. R. Ingalls. 1994a. The post-ruminal digestion of dry matter, nitrogen and amino acids in wheat-based distillers dried grains and canola meal. Anim. Feed Sci. Technol. 49:173-188.

Boila, R. J., and J. R. Ingalls. 1994b. The ruminal degradation of dry matter, nitrogen and amino acids in wheat-based distillers dried grains in sacco. Anim. Feed Sci. Technol. 48:57-72.

Borucki Castro, S. I., L. E. Phillip, H. Lapierre, P. W. Jardon, and R. Berthiaume. 2007. Ruminal degradability and intestinal digestibility of protein and amino acids in treated soybean meal products. J. Dairy Sci. 90:810-822.

Boucher, S. E., S. Calsamiglia, C. M. Parsons, H. H. Stein, M. D. Stern, P. S. Erickson, P. L. Utterback, and C. G. Schwab. 2009. Intestinal digestibility of amino acids in rumen-undegraded protein estimated using a precision-fed cecectomized rooster bioassay: II. Distillers dried grains with solubles and fish meal. J. Dairy Sci. 92:6056-6067.

CCAC (Canadian Council on Animal Care). 1993. Guide to the Care and Use of Experimental Animals. Vol. 1. 2nd ed. E. D. Olfert, B. M. Cross, and A. A. McWilliam, ed. CCAC, Ottawa, Canada.

Chen, Z. H., G. A. Broderick, N. D. Luchini, B. K. Sloan, and E. Devillard. 2011. Effect of feeding different sources of rumen-protected methionine on milk production and N-utilization in lactating dairy cows. J. Dairy Sci. 94:1978-1988.

Christen, K. A., D. J. Schingoethe, K. F. Kalscheur, A. R. Hippen, K. K. Karges, and M. L. Gibson. 2010. Response of lactating dairy cows to high protein distillers grains or 3 other protein supplements. J. Dairy Sci. 93:2095-2104.

Denham, S. C., G. A. Morantes, D. B. Bates, and J. E. Moore. 1989. Comparison of two models used to estimate in situ nitrogen disappearance. J. Dairy Sci. 72:708-714.

FOBI Network. 2011. Wheat DDGS Feed Guide, 1st ed. Feed Opportunities for Biofuels Industries. Canadian International Grains Institute, Winnipeg, Canada.

Gerrard, J. A. 2002. Protein-protein crosslinking in food: Methods, consequences, applications. Trends Food Sci. Technol. 13:391399.

Gonzalez, J., C. Centeno, F. Lamrani, and C. A. Rodrigez. 2001. In situ rumen degradation of amino acids from different feeds corrected for microbial contamination. Anim. Res. 50:253-264.

Harstad, O. M., and E. Prestløkken. 2000. Effective rumen degradability and intestinal indigestibility of individual amino acids in solvent-extracted soybean meal and xylose-treated SBM determined in situ. Anim. Feed Sci. Technol. 83:31-47.

Harstad, O. M., and E. Prestløkken. 2001. Rumen degradability and intestinal indigestibility of individual amino acids in corn gluten meal, canola meal and fish meal determined in situ. Anim. Feed Sci. Technol. 94:127-135.

Heendeniya, R. G., D. A. Christensen, D. D. Maenz, J. J. McKinnon, and P. Yu. 2012. Protein fractionation byproduct from canola meal for dairy cattle. J. Dairy Sci. 95:4488-4500.

Holm, J., I. Bjorck, A. Drews, and N. G. Asp. 1996. A rapid method for the analysis of starch. Starch 38:224-226.

Hubbard, K. J., P. J. Kononoff, A. M. Gehman, J. M. Kelzer, K. Karges, and M. L. Gibson. 2009. Short communication: The effect of feeding high protein distillers dried grains on milk production of Holstein cows. J. Dairy Sci. 92:2911-2914.
Huhtanen, P., M. Hetta, and C. Swensson. 2011. Evaluation of canola meal as a protein supplement for dairy cows: A review and a metaanalysis. Can. J. Anim. Sci. 91:529-543.

Hvelplund, T., and M. R. Weisbjerg. 2000. In situ techniques for the estimation of protein degradability and post rumen availability. Pages 233-258 in Forage Evaluation in Ruminant Nutrition. D. I. Givens, E. Owen, R. F. E. Axford, and H. M. Omed, ed. CABI Publishing, Wallingford, Oxfordshire, UK.

Illg, D. J., J. L. Sommerfeldt, and D. J. Schingoethe. 1987. Lactational and systemic responses to the supplementation of protected methionine in soybean meal diets. J. Dairy Sci. 70:620-629.

INRA. 2007. Nutrition of Cattle, Sheep and Goats: Animal NeedsValues of Feeds. Quae Editions, Paris, France.

Kelzer, J. M., P. J. Kononoff, L. O. Tedeschi, T. C. Jenkins, K. Karges, and M. L. Gibson. 2010. Evaluation of protein fractionation and ruminal and intestinal digestibility of corn milling co-products. J. Dairy Sci. 93:2803-2815.

Kleinschmit, D. H., J. L. Anderson, D. J. Schingoethe, K. F. Kalscheur, and A. R. Hippen. 2007. Ruminal and intestinal degradability of distillers grains plus solubles varies by source. J. Dairy Sci. 90:2909-2918.

Li, C., J. Q. Li, W. Z. Yang, and K. A. Beauchemin. 2012. Ruminal and intestinal amino acid digestion of distiller's grain vary with grain source and milling process. Anim. Feed Sci. Technol. 175:121-130.

Li, Y. L., T. A. McAllister, K. A. Beauchemin, M. L. He, J. J. McKinnon, and W. Z. Yang. 2011. Substitution of wheat dried distillers grains with solubles for barley grain or barley silage in feedlot cattle diets: Intake, digestibility, and ruminal fermentation. J. Anim. Sci. 89:2491-2501.

Licitra, G., T. M. Hernandez, and P. J. Van Soest. 1996. Standardization of procedures for nitrogen fractionation of ruminant feeds. Anim. Feed Sci. Technol. 57:347-358.

Little, C. O., G. E. Mitchell, and G. D. Potter. 1968. Nitrogen in the abomasum of wethers fed different protein sources. J. Anim. Sci. $27: 1722-1726$.

Madsen, J., and T. Hvelplund. 1994. Prediction of in situ degradability in the rumen. Results of a European ringtest. Livest. Prod. Sci. 39:201-212.

Martineau, R., D. R. Ouellet, and H. Lapierre. 2013. Feeding canola meal to dairy cows: A meta-analysis on lactational responses. J. Dairy Sci. 96:1701-1714.

Michalet-Doreau, B., and M. Y. Ould-Bah. 1992. In vitro and in sacco methods for the estimation of dietary nitrogen degradability in the rumen: A review. Anim. Feed Sci. Technol. 40:57-86.

Mjoun, K., K. F. Kalscheur, A. R. Hippen, and D. J. Schingoethe. 2010. Ruminal degradability and intestinal digestibility of protein and amino acids in soybean and corn distillers grains products. J. Dairy Sci. 93:4144-4154.

Mustafa, A. F., D. A. Christensen, and J. J. McKinnon. 1996. Chemical characterization and nutrient availability of high and low fiber canola meal. Can. J. Anim. Sci. 76:579-586.

Mustafa, A. F., D. A. Christensen, J. J. McKinnon, and R. Newkirk. 2000. Effects of stage of processing of canola seed on chemical composition and in vitro protein degradability of canola meal and intermediate products. Can. J. Anim. Sci. 80:211-214.

Newkirk, R. 2009. Canola Meal: Feed Industry Guide. 4th ed. Canadian International Grains Institute, Canada.

NorFor (Nordic Feed Evaluation System). 2010. NorFor feedtables. http://www.norfor.info/.

NRC. 2001. Nutrient Requirements of Dairy Cattle, 7th rev. Natl. Acad. Press ed., Washington, DC.

Nuez-Ortín, W. G., and P. Yu. 2010. Estimation of ruminal and intestinal digestion profiles, hourly effective degradation ratio and potential $\mathrm{N}$ to energy synchronization of co-products from bioethanol processing. J. Sci. Food Agric. 90:2058-2067.

O'Mara, F. P., J. J. Murphy, and M. Rath. 1997. The amino acid composition of protein feedstuffs before and after ruminal incubation and after subsequent passage through the intestines of dairy cows. J. Anim. Sci. 75:1941-1949. 
Oba, M., G. B. Penner, T. D. Whyte, and K. Wierenga. 2010. Effects of feeding triticale dried distillers grains plus solubles as a nitrogen source on productivity of lactating dairy cows. J. Dairy Sci. 93:2044-2052.

Ørskov, E. R., and I. McDonald. 1979. The estimation of protein degradability in the rumen from incubation measurements weighted according to rate of passage. J. Agric. Sci. 92:499-503.

Piepenbrink, M. S., and D. J. Schingoethe. 1998. Ruminal degradation, amino acid composition, and estimated intestinal digestibilities of four protein supplements. J. Dairy Sci. 81:454-461.

Prestløkken, E. 1999. In situ ruminal degradation and intestinal digestibility of dry matter and protein in expanded feedstuffs. Anim. Feed Sci. Technol. 77:1-23.

Robinson, P. H., K. Karges, and M. L. Gibson. 2008. Nutritional evaluation of four co-product feedstuffs from the motor fuel ethanol distillation industry in the Midwestern USA. Anim. Feed Sci. Technol. 146:345-352.

SAS Institute. 2001. SAS User's Guide, version 9.1. SAS Institute, Cary, NC.

Schingoethe, D. J., K. F. Kalscheur, A. R. Hippen, and A. D. Garcia 2009. Invited review: The use of distillers products in dairy cattle diets. J. Dairy Sci. 92:5802-5813.
Statistic Canada. 2011. Canada's national statistic agency. http:// www.statcan.gc.ca/.

Van Soest, P. J., J. B. Robertson, and B. A. Lewis. 1991. Methods for dietary fiber, neutral detergent fiber, and nonstarch polysaccharides in relation to animal nutrition. J. Dairy Sci. 74:3583-3597.

van Straalen, W. M., J. J. Odinga, and W. Mostert. 1997. Digestion of feed amino acids in the rumen and small intestine of dairy cows measured with nylon-bag techniques. Br. J. Nutr. 77:83-97.

Zhang, S. Z., G. B. Penner, W. Z. Yang, and M. Oba. 2010. Effects of partially replacing barley silage or barley grain with dried distillers grains with solubles on rumen fermentation and milk production of lactating dairy cows. J. Dairy Sci. 93:3231-3242.

Zhang, X., and P. Yu. 2012. Molecular basis of protein structure in combined feeds (hulless barley with bioethanol coproduct of wheat dried distillers grains with solubles) in relation to protein rumen degradation kinetics and intestinal availability in dairy cattle. J. Dairy Sci. 95:3363-3379. 